\title{
Metabolic syndrome, insulin resistance and other cardiovascular risk factors in university students
}

\author{
Síndrome metabólica, resistência insulínica \\ e outros fatores de risco cardiovascular em universitários
}

\author{
José Bonifácio Barbosa ${ }^{1}$ \\ Alcione Miranda dos Santos ${ }^{1}$ \\ Marcelo Mesquita Barbosa ${ }^{2}$ \\ Márcio Mesquita Barbosa ${ }^{2}$ \\ Carolina Abreu de Carvalho ${ }^{1}$ \\ Poliana Cristina de Almeida Fonseca ${ }^{1}$ \\ Jessica Magalhães Fonseca ${ }^{1}$ \\ Maria do Carmo Lacerda Barbosa ${ }^{3}$ \\ Eduarda Gomes Bogea ${ }^{1}$ \\ Antônio Augusto Moura da Silva ${ }^{1}$
}

${ }^{1}$ Programa de PósGraduação em Saúde Coletiva, Universidade Federal do Maranhão (UFMA). Av. Barão de Itapary 227, Centro. 65020-070 São Luís MA. josebbarbosa@uol.com.br ${ }^{2}$ Programa de Pós-

Graduação em Ciências da Saúde, UFMA. São Luís MA Brasil.

${ }^{3}$ Programa de Pós-

Graduação da Rede

Nordeste de Biotecnologia. Recife PE Brasil.

\begin{abstract}
A cross-sectional population-based study using questionnaire and anthropometric data was conducted on 968 university students of São Luis, Brazil, from which 590 showed up for blood collection. In the statistical analysis the Student t-test, Mann-Whitney and chi-square tests were used. The prevalence of metabolic syndrome by the Joint Interim Statement (JIS) criteria was $20.5 \%$, almost three times more prevalent in men $(32.2 \%)$ than in women $(13.5 \%)(P<0.001)$. The prevalence of insulin resistance was $7.3 \%$ and the prevalence of low HDL-cholesterol was high $(61.2 \%)$, both with no statistically significant differences by sex. Men showed a higher percentage of smoking, overweight, high blood pressure, high blood glucose and increased fasting hypertriglyceridemia. Women were more sedentary. University students of private institutions had higher prevalences of sedentary lifestyle, obesity, abdominal obesity, elevated triglycerides and metabolic syndrome than students from public institutions. High prevalences of metabolic syndrome, insulin resistance and other cardiovascular risk factors were found in this young population. This suggests that the burden of these diseases in the future will be increased.
\end{abstract}

Key words Metabolic Syndrome X, Insulin resistance, Risk factors, Cardiovascular diseases, Young adult
Resumo Estudo transversal de base populacional, usando questionários e medidas antropométricas, feito em 968 universitários de São Luís, dos quais 590 realizaram também coleta de sangue. Na análise estatística foram utilizados os testes $t$ de Student, Mann-Whitney e qui-quadrado. A prevalência de síndrome metabólica pelo critério Joint Interim Statement (JIS) foi de 20,5\%, sendo quase três vezes mais prevalente nos homens $(32,2 \%)$ do que nas mulheres $(13,5 \%)(P<0,001)$. A prevalência de resistência insulínica foi de 7,3\% e a de HDL-colesterol diminuído foi elevada (61,2\%), ambas sem diferença estatisticamente significante por sexo. Os homens apresentaram maior percentual de tabagismo, sobrepeso, hipertensão arterial, glicemia em jejum aumentada e hipertrigliceridemia. As mulheres eram mais sedentárias. Os universitários de instituições privadas tiveram maiores prevalências de sedentarismo, obesidade, obesidade abdominal, triglicerídeos aumentadose sindrome metabólica do que os alunos de instituições públicas. Prevalências elevadas de sindrome metabólica, resistência insulínica e outros fatores de risco cardiovascular foram encontradas nesta população jovem. Isto sugere que a carga destas doenças será elevada no futuro.

Palavras-chave Síndrome metabólica X, Resistência insulínica, Fatores de risco, Doenças cardiovasculares, Adulto jovem 


\section{Introduction}

Cardiovascular diseases are a serious public health problem in Brazil, currently being considered the main cause of death and disability worldwide ${ }^{1,2}$. Mortality rates from cardiovascular diseases (CVDs) have greatly increased in middle-income countries, such as Brazil ${ }^{2}$. According to the Ministry of Health, $30.7 \%$ of the total deaths in Brazil in 2011were caused by cardiovascular diseases ${ }^{3}$.

Although each cardiovascular risk factor in isolation has an impact on health, very often these risk factors are aggregated in individuals $s^{4,5}$. This aggregation of cardiovascular risk factors, such as abdominal obesity and insulin resistance, comprises the metabolic syndrome (MS) ${ }^{2}$. MS increases mortality from CVD by 2.5 and is recognized worldwide as a major public health problem ${ }^{6}$.

This set of cardiovascular risk factors in the adult and elderly population is a common finding well described in the literature. However, studies have shown the increasingly occurrence of cardiovascular events and risk factors among adolescents and young adults $s^{1,7,8}$. Few data regarding the prevalence of MS, insulin resistance (IR) and other risk factors for CVD in young adults are available in Brazil. Most existing studies have usually been performed in small samples from selected institutions ${ }^{1,9,10}$. In the few available population-based studies the prevalence of MS varied from $15.8 \%$ in Vitória ${ }^{11}$ to $24.4 \%$ in the Federal District ${ }^{12}$ among people aged 25-34 years. In young adults aged 23-25 years from Ribeirão Preto, the prevalence of MS was $7.6 \%$, whereas the prevalence of insulin resistance was $13.9 \%{ }^{13}$.

Due to the scarcity of studies that addressed MS, IR and other cardiovascular risk factors in young adults in Brazil and especially in the Northeast, the region in which these events are on the increase ${ }^{12}$, this study was carried out with the objective of estimating the prevalence of MS, IR and other modifiable and non-modifiable risk factors for cardiovascular diseases among college students in a population-based sample in São Luís, Maranhão, Brazil. Differences in cardiovascular risk factors between men and women and between public and private institutions were also assessed.

\section{Methods}

The present cross-sectional population-based study was conducted in three public and six private Higher Education Institutions (HEIs) in the city of São Luís, Maranhão, Brazil. The data are from a probabilistic sample of college students, and were collected from August 2011 to October 2012.

\section{Sampling}

Nine HEIs were included in the sampling frame. Together, they accounted for $95 \%$ of all university students in the city. Institutions with small numbers of students were not included. Sampling was carried out in clusters in two stages. In the first stage disciplines were selected and in the second stage students were selected.The sample was stratified into two groups: public and private institutions. In each institution a list of all disciplines offered was obtained. From this list in each stratum a simple random sampling of disciplines was carried out, with probability proportional to the number of students in each institution in relation to the total number of students in all universities. Then, in each selected discipline, 12 students were randomly selected to participate in the study. The probability of selection for each student was conditional on the number of disciplines that he/she was attending. The higher the number of disciplines the student was attending the higher the probability of he/she being selected. Thus, probabilities of selection were corrected for multiplicity, considering the number of disciplines taken by each student.

The estimated sample size was 1276 students. This sample size allowed estimating a prevalence of approximately $50 \%$ with a margin of error of $3 \%$ and $95 \%$ confidence. With this sample size it was possible to detect an $8 \%$ difference in the prevalence of metabolic syndrome (estimated at $10 \%)$ between the exposed and unexposed individuals, assuming a $5 \%$ probability of type I error, settling at $80 \%$ the study power and considering a design effect of 2 . The final sample was of 968 students. Losses amounted to $24.1 \%$ due to refusals or absence of the student in the classroom on the day of interview. 


\section{Data collection}

Data were obtained through interviews with the students by means of a standardized questionnaire. The following data were collected: age, sex, education of the household head (College/ University degree, high school, primary or middle school), Brazilian economic classification (based on the possession of goods and education of the family head, classified into A to E, with A being the most educated and wealthy and $\mathrm{E}$ the least), university type (public or private), marital status, family income, self-reported skin color (classified according to the Brazilian Institute of Geography and Statistics - IBGE ${ }^{11}$ - into black, brown/mullato and white), religion, possession of health insurance, participation in the ProUni (University for Everyone Program), tobacco and alcohol use in the last month. Smoking was considered the consumption of at least one cigarette in the last month. Fat intake was assessed by the Block score, and considered high when $>27^{14}$.

Blood pressure and anthropometric measurements were also carried out and a blood sample was drawn for laboratory tests. Of the 968 participants, 590 (61.0\%) attended blood collection.

Blood pressure was measured twice at five-minute intervals and only the lowest value was considered in data analysis. We used digital Omron ${ }^{\circledR}$ automated devices with different cuff sizes, following the VI Brazilian Guidelines on hypertension ${ }^{15}$.

To check participant's weight and body fat percentage (by bipolar bioelectrical impedance) the Tanita ${ }^{\circledR}$ (BC533) portable scale was used. The procedure was performed with the student standing barefoot on the metal surface conductive equipment according to the manufacturer's guidelines. Percent body fat cutoff points followed guidelines by Lohman ${ }^{16}$.

The measurement of height was held in the Alturaexata ${ }^{\circledR}$ brand stadiometer with the subject standing barefoot, heels together, back straight and arms extended alongside the body. Body Mass Index (BMI) was calculated according to the formula: $\mathrm{BMI}=$ weight $(\mathrm{kg}) /$ height $(\mathrm{m})^{2}$. BMI classification was performed according to the cutoff points proposed by the World Health Organization in $1998^{17}$.

Waist circumference (WC) was measured with the student standing, using a non-stretchable tape at the midpoint between the iliac crest and the outer face of the last rib, and readings were made at the time of expiration ${ }^{18}$. WC values greater than $102 \mathrm{~cm}$ for men and $88 \mathrm{~cm}$ for women (National Cholesterol Education Program Adult Treatment Panel III - NCEP ATPIII) and $90 \mathrm{~cm}$ for men and $80 \mathrm{~cm}$ for women (International Diabetes Federation-IDF and Joint Interim Statement-JIS) were considered indicative of risk for cardiovascular diseases ${ }^{19}$.

Hip circumference (HC) was obtained in the region of the largest circumference between the waist and the thigh, with a non-stretchable tape. With data from WC and HC, the waist-hip ratio (WHR) was calculated. WHR values greater than 0.90 for men and 0.85 for women were considered of risk ${ }^{18}$.

The waist-to-height (WHtR) was calculated based on measurements of WC and height. WHtR values greater than or equal to 0.52 for men and 0.53 for women were considered of risk for $\mathrm{CVD}^{18}$.

Fasting glucose and lipids (Triglycerides, HDL-c) were measured in the ADVIA 1650 equipment (Bayer CO, USA) and fasting insulin in the IMMULITE 2000 (Siemens) unit.

For the calculation of IR blood glucose levels and fasting insulin were used. IR was measured by the Homeostasis Model Assessment - Insulin Resistance (HOMA-IR) according to the following formula: HOMA-IR = insulin $(\mathrm{U} / \mathrm{mL}) \times$ (glucose $\mathrm{mg} / \mathrm{dL} \div 18) \div 22.5$. HOMA-IR estimates insulin sensitivity and beta cell function from the pancreas $^{20,21}$. Insulin resistance was defined as HOMA-IR $>2,7^{22}$.

The diagnosis of MS was completed by the NCEP ATPIII, when attended at least three of the five following criteria: triglycerides $>150 \mathrm{mg} / \mathrm{dl}$; $\mathrm{HDL}-\mathrm{C}<50 \mathrm{mg} / \mathrm{dl}$ in women and $<40 \mathrm{mg} / \mathrm{dl}$ in men, fasting glucose $>100 \mathrm{mg} / \mathrm{dl}$, waist circumference $>102 \mathrm{~cm}$ for men and $>88 \mathrm{~cm}$ for women and blood pressure $>130 \times 85 \mathrm{mmHg}$. MS according to IDF was defined when waist circumference $>90 \mathrm{~cm}$ for men and $>80 \mathrm{~cm}$ for women and two of the other above mentioned components were present. MS was defined according to JIS as the presence of three of the above five mentioned criteria with a lower cutoff point for the WC: $>$ $90 \mathrm{~cm}$ for men and $>80 \mathrm{~cm}$ for women ${ }^{19}$. Following IDF recommendations adult criteria was used for adolescents $\geq 16$ years of age ${ }^{23}$.

Physical activity was assessed by applying the International Physical Activity Questionnaire (IPAQ short version). Individuals were classified into active or sedentary according to proposed IPAQ guidelines ${ }^{24}$. 


\section{Statistical Analysis}

For descriptive analysis, the mean and standard deviation were calculated for quantitative variables with normal distribution and the median and 25th and 75th percentiles for those with non-normal distribution. Percentages were presented for qualitative variables. Data were processed and analyzed in Excel and Stata 12.0. Differences in prevalence by sex were tested by the chi-square and differences in quantitative variables were verified using the Student $t$ test or the nonparametric Mann-Whitney test, when appropriate. The significance level was set at 0.05 .

The probability of selection for each student was calculated for each sampling stage. For the first stage it was the ratio between the number of students in each class divided by the total number of subjects offered in each university. For the second stage it was the number of students interviewed, divided by the number of students attending each discipline. These two probabilities were then multiplied by each other and then by the number of disciplines taken by each student. In the statistical analysis we took into account stratification according to university type (public or private) and the design effect through svy commands in Stata. Data were weighted by the inverse probability of selection of each participant. Since $39 \%$ of those who participated did not attend blood collection, differences in percentage of losses according to some variables were evaluated using the chi-square test. To reduce selection bias the inverse probability weighting procedure also took non-response into account. Variables that were associated with participation were identified in two-way tables by chi-square tests. Then, probabilities of participation in laboratorial exams were estimated by logistic regression including family income, schooling of the head of family, stratum (public or private university), religion and health insurance as predictors. The final weight $\mathrm{w}_{\mathrm{i}}$ for individual $\mathrm{i}$ used in the analysis of laboratorial exams was then the product of two weights: the inverse of the probability of being sampled and the inverse of the probability of participation in blood collection.

\section{Ethical aspects}

This study was approved by the Research Ethics Committee of the University Hospital of the Federal University of Maranhão. Each participant signed the Informed Consent Statement Form.

\section{Results}

The sample consisted of 968 students, 614 females $(62 \%)$ and 354 males (38\%). Age varied from 16 to 62 years. The median age was 22 years for men and 23 years for women.

A higher percentage of students had family incomes from 2 to 4 minimum wages (35.5\%), had household heads with secondary education (56.3\%), belonged to the classes $\mathrm{A} / \mathrm{B}(45.8 \%)$ or attended private universities (65.6\%). Fifty-two percent reported being brown/mullato, $82.1 \%$ were living without a partner, $59.2 \%$ profess the Catholic religion, and 53\% had no health insurance. A small percentage (8.9\%) participated in the ProUni (University for Everyone Program) (Table 1).

Measures of central tendency (mean or median) of weight, height, body mass index, waist circumference, hip circumference, waist-to-hip ratio, waist-to-height ratio, systolic and diastolic $\mathrm{BP}$, fasting glucose and triglycerides were higher for men compared to women $(\mathrm{P}<0.01)$. Fasting insulin, body fat percentage and HDL-cholesterol were higher among women than men. Age ( $\mathrm{p}$ $=0.657)$ and HOMA-IR $(\mathrm{p}=0.196)$, presented no statistically significant difference when comparing men and women (Table 2).

Smoking was uncommon (4.3\%), but men smoked nearly four times more than women ( $8.0 \%$ vs $2.1 \%, p<0.001)$. Consumption of alcohol in the last month was $50.2 \%$, with higher consumption among men (58.6\%) than among women $(45 \%, \mathrm{p}=0.004)$. The prevalence of physical inactivity was $69.6 \%$, whereas women were more sedentary $(76.1 \%)$ than men $(59 \%$, $\mathrm{p}<0.001)$. High fat consumption has been observed in $29.9 \%$, being marginally higher for women $(32.9 \%)$ than for men $(25.1 \%, \mathrm{p}=0.058)$ (Table 3).

According to BMI, 29.5\% were overweight and $8.7 \%$ obese. The prevalence of obesity was higher for men (12\%) than for women $(6.7 \%)$. Men also had a higher prevalence of overweight $(39.1 \%)$ than women $(23.7 \%)(p<0.001)$. High waist-to-hip ratio was observed in $21.1 \%$ and the waist-to-height ratio was increased in $27.9 \%$, with higher values for men. By body fat percentage $23 \%$ were obese, with no difference between sexes $(\mathrm{p}=0.525)$ (Table 3$)$.

High waist circumference by the NCEP criteria was observed in $13.7 \%$ and $36 \%$ according to IDF, with no difference between sexes. The prevalence of MS by the NCEP criteria was $14.9 \%$ (95\% CI 10.5\% - 20.7\%), being higher for men 
Table 1. Characteristics of the university students of São Luís, Maranhão, Brazil, 2011-12.

\begin{tabular}{|c|c|c|}
\hline Variables & $\mathbf{n}$ & $\%$ weighted \\
\hline $\begin{array}{l}\text { Sex } \\
\quad \text { Female } \\
\quad \text { Male }\end{array}$ & $\begin{array}{l}614 \\
354\end{array}$ & $\begin{array}{l}62.0 \\
38.0\end{array}$ \\
\hline $\begin{array}{l}\text { Age (years) } \\
\quad \leq 20 \\
21 \text { to } 30 \\
\geq 30\end{array}$ & $\begin{array}{l}284 \\
540 \\
144\end{array}$ & $\begin{array}{l}24.8 \\
58.7 \\
16.5\end{array}$ \\
\hline $\begin{array}{l}\text { Family income (minimum wages) } \\
\qquad 2 \\
\text { 2to } 4 \\
\text { 5to } 9 \\
\geq 10\end{array}$ & $\begin{array}{r}90 \\
331 \\
315 \\
217\end{array}$ & $\begin{array}{l}10.4 \\
35.5 \\
33.4 \\
20.7\end{array}$ \\
\hline $\begin{array}{l}\text { Schooling of the head of family } \\
\text { College/University Degree } \\
\text { High School } \\
\text { Primary or Middle School }\end{array}$ & $\begin{array}{l}277 \\
530 \\
145\end{array}$ & $\begin{array}{l}28.7 \\
56.3 \\
15.0\end{array}$ \\
\hline $\begin{array}{l}\text { Brazilian Economic Classification } \\
\text { A/B } \\
\text { C } \\
\text { D/E }\end{array}$ & $\begin{array}{l}411 \\
426 \\
131\end{array}$ & $\begin{array}{l}45.8 \\
41.1 \\
13.1\end{array}$ \\
\hline $\begin{array}{l}\text { Stratum } \\
\text { Public } \\
\text { Private }\end{array}$ & $\begin{array}{l}404 \\
564\end{array}$ & $\begin{array}{l}34.4 \\
65.6\end{array}$ \\
\hline $\begin{array}{l}\text { Marital status }^{\mathrm{a}} \\
\text { Without a companion } \\
\text { Consensual union } \\
\text { Married }\end{array}$ & $\begin{array}{r}798 \\
37 \\
132\end{array}$ & $\begin{array}{r}82.1 \\
3.6 \\
14.3\end{array}$ \\
\hline $\begin{array}{l}\text { Skin color } \\
\text { White } \\
\text { Black } \\
\text { Mullato }\end{array}$ & $\begin{array}{l}289 \\
178 \\
496\end{array}$ & $\begin{array}{l}28.4 \\
19.6 \\
52.0\end{array}$ \\
\hline $\begin{array}{l}\text { Religion }^{\mathrm{a}} \\
\text { Catholic } \\
\text { Evangelic } \\
\text { Other } \\
\text { No religion }\end{array}$ & $\begin{array}{r}552 \\
298 \\
28 \\
88\end{array}$ & $\begin{array}{r}59.2 \\
29.8 \\
2.3 \\
8.7\end{array}$ \\
\hline $\begin{array}{l}\text { Health Insurance } \\
\text { Yes } \\
\text { No }\end{array}$ & $\begin{array}{l}418 \\
550\end{array}$ & $\begin{array}{l}47.0 \\
53.0\end{array}$ \\
\hline $\begin{array}{l}\text { Enrolled in ProUni }{ }^{\text {a }} \\
\text { Yes } \\
\text { No }\end{array}$ & $\begin{array}{r}73 \\
894\end{array}$ & $\begin{array}{r}8.9 \\
91.1\end{array}$ \\
\hline
\end{tabular}

a Totals do not add to 968 because of missing values ProUni: University for All Program.

(22.1\%) than for women (10.7\%) $(\mathrm{P}=0.027)$. By the IDF definition, the prevalence was $18.3 \%$ (95\% CI $14.1 \%-23.4 \%)$, and also higher in men (26.6\%) than in women $(13.4 \%)(\mathrm{P}=0.022)$. For the most current criteria, the JIS, the prevalence of MS was $20.5 \%$ (95\% CI $15.8 \%-26.0 \%$ ), nearly three times more prevalent in men (32.2\%) than in women $(13.5 \%)(\mathrm{P}<0.001)$. The prevalence of insulin resistance, measured by HOMA-IR was $7.3 \%$ (95\% CI 4.6\% - 11.2\%) with no statistically significant difference between men and women $(\mathrm{p}=0.636)($ Table 4$)$.

The weighted total prevalence of hypertension was $27.1 \%$, being much higher for males $(46.3 \%)$ than for females $(15.3 \%)(\mathrm{p}<0.001)$. Increased fasting glucose was detected in $4.5 \%$, with higher percentages for men $(7.8 \%)$ than for women $(2.6 \%)(\mathrm{p}=0.047)$. Triglycerides were elevated in $17.3 \%$. More men $(28.7 \%)$ than women $(10.5 \%)(\mathrm{p}=0.002)$ presented hypertriglyceridemia. Low HDL-cholesterol was detected in $61.2 \%$, with no difference between sexes $(\mathrm{p}=$ 0.072) (Table 4).

Higher prevalences of physical inactivity $(\mathrm{p}$ $=0.019)$, obesity according to BMI $(\mathrm{p}=0.024)$, high waist-to-hip ratio $(\mathrm{p}=0.001)$, increased waist-to-height ratio $(\mathrm{p}<0.001)$, increased body fat percentage $(p=0.001)$ were observed among students from private compared with those attending public institutions (Table 5). Increased waist circumference by the NCEP and the IDF criteria ( $p=0.007$ and $p<0.001$, respectively) and high triglycerides $(\mathrm{p}=0.015)$ were also higher for students attending private institutions $(\mathrm{Ta}-$ ble 6). Prevalence of MS according to the NCEP and IR did not differ between students from public and private universities. However, according to the IDF and JIS criteria, students from private institutions had higher prevalences of MS compared to those from public ones (Table 6).

Table 7 compares characteristics of students who did or did not show up for collection of blood samples. Greater percentage of losses was observed among university students with higher family income $(p=0.034)$, greater education of the household head $(p=0.003)$, from private institutions $(\mathrm{p}<0.001)$, who had health insurance $(p=0.012)$, from the catholic religion or from those who had no religion $(p=0.009)$.

\section{Discussion}

The main findings of this study were high prevalences of decreased HDL-C (61.2\%), hypertension $(27.1 \%)$ and metabolic syndrome $(20.5 \%$ according to JIS). In addition, higher prevalence of cardiovascular risk factors were observed in male college students and in those attending private institutions. It was noteworthy that, in this predominantly middle and high-income young 
Table 2. Distribution of quantitative variables among university students by sex, São Luís, Maranhão, Brazil, 2011-12.

\begin{tabular}{|c|c|c|c|}
\hline Variables & Females & Males & P-value ${ }^{a}$ \\
\hline Age (years) ${ }^{b}$ & $23(21-28)$ & $22(21-27)$ & 0.657 \\
\hline Weight $(\mathrm{kg})^{\mathrm{b}}$ & $58.3(51.9-64.9)$ & $74.9(65.8-84.2)$ & $<0.001$ \\
\hline Height $(\mathrm{cm})^{\mathrm{c}}$ & $159.7(6.1)$ & $172.3(6.4)$ & $<0.001$ \\
\hline Body mass index $(\mathrm{Kg} / \mathrm{m} 2)^{\mathrm{b}}$ & $22.7(20.4-25.5)$ & $25.2(22.6-27.9)$ & $<0.001$ \\
\hline Waist circumference $(\mathrm{cm})^{c}$ & $76.7(10.5)$ & $87.3(11.9)$ & $<0.001$ \\
\hline Hip circumference $(\mathrm{cm})^{\mathrm{c}}$ & $97.5(8.2)$ & $100.6(8.1)$ & 0.001 \\
\hline Waist-to-hip ratio ${ }^{c}$ & $0.78(0.07)$ & $0.86(0.07)$ & $<0.001$ \\
\hline Waist-to-height ratio ${ }^{c}$ & $0.48(0.07)$ & $0.51(0.07)$ & $<0.001$ \\
\hline Body fat percentage ${ }^{\text {cd }}$ & $26.2(8.1)$ & $19.6(7.5)$ & $<0.001$ \\
\hline Systolic blood pressure $(\mathrm{mmHg})^{2}$ & $111.5(104.5-119)$ & $127(120.5-134.5)$ & $<0.001$ \\
\hline Glycemia $(\mathrm{mg} / \mathrm{dl})^{\mathrm{b}}$ & $82(77-87)$ & $87(83-93)$ & 0.010 \\
\hline Insulinemia $(\mu \mathrm{U} / \mathrm{mL})^{\mathrm{b}}$ & $3.59(2-7.23)$ & $2.4(2-6.06)$ & 0.008 \\
\hline Triglycerides $(\mathrm{mg} / \mathrm{dl})^{\mathrm{b}}$ & $77(55-105)$ & $101(73-160)$ & $<0.001$ \\
\hline HDL-cholesterol $(\mathrm{mg} / \mathrm{dl})^{\mathrm{c}}$ & $47.0(11.3)$ & $38.9(8.0)$ & $<0.001$ \\
\hline HOMA-IR ${ }^{b}$ & $0.73(0.41-1.54)$ & $0.60(0.43-1.34)$ & 0.196 \\
\hline
\end{tabular}

${ }^{a} \mathrm{P}$ value calculated by the Student's $\mathrm{t}$ test when variables presented normal distribution or the Mann-Whitney test otherwise; ${ }^{\mathrm{b}}$ Variables with non-normal distribution: values represent median (25th percentile -75 th percentile); ${ }^{\mathrm{C}}$ Variables with normal distribution: values represent mean (standard deviation); ${ }^{\mathrm{d}}$ Body fat percentage estimated by bipolar bioelectrical impedance. HDL: High Density Lipoprotein; HOMA -IR: Homeostasis Model Assessment - insulin resistance.

population with a median age of 22 years, the prevalence of insulin resistance was $7.3 \%$.

In a study by Bustos and colleagues, performed in a young population with roughly the same age in Limache (L), Chile, and Ribeirão Preto (RP), Brazil ${ }^{13}$, high prevalences of some of the components of MS were also observed. Low HDL-c was $61.2 \%$ in this study, close to the value obtained in Limache $(66.7 \%)$, but higher than the prevalence obtained in RP (42.2\%). Raised blood pressure was observed in $15.5 \%$ in Limache and $23.1 \%$ in RP whereas in this study a higher prevalence was estimated, $27.1 \%$. Abdominal obesity was observed in $19.3 \%$ in Limache and $12.7 \%$ in RP whereas in this study its prevalence was $13.7 \%$. It is noteworthy that in this study the prevalence of smoking was much lower $(4.3 \%)$ than in Ribeirão Preto $(17.2 \%)$ or Limache $(56.4 \%)$. In contrast, the prevalence of a sedentary lifestyle was far greater in this study $(69.6 \%)$ than in Ribeirão Preto $(33.2 \%)$ or Limache $(38.3 \%)$.

Bustos et al. ${ }^{13}$, using the NCEP ATPIII definition, showed a $10.1 \%$ prevalence of MS in Limache and 7.6\% in Ribeirão Preto. In this study, the prevalence of MS by the same definition was $14.9 \%$, higher than the values observed in these studies. These differences could be explained by the time of completion of the studies, as the data in
Limache and Ribeirão Preto are from 2002/2004 while data in this study are from 2011/2012. In addition, these differences might be due to the fact that Ribeirão Preto and Limache samples were drawn from the entire population whereas this study sample was drawn from the population of university students that tend to be better off. Yet paradoxically in this study the prevalence of RI was $7.3 \%$, which is much lower than that observed in Ribeirão Preto in 2002/2004 (13.9\%) and Limache $(34.5 \%)$. Differences in the cutoff points used (IR $>2.7$ in this study and IR $>2.53$ in the other studies) would not explain such large differences. In Ribeirão Preto, the prevalence of MS was higher among men, which agrees with data from this study. However, the prevalence of IR in Ribeirão Preto was also higher among men, while in this study there was no difference by sex.

In a study of 2,130 adults aged greater than 18 years old in Brasilia, a 32\% prevalence of MS by the JIS criterion ${ }^{24}$ was observed. The prevalence of MS in the previous study in the youngest age group (18-24 years) was $24.8 \%$, higher than that found in this study by the same criterion (20.5\%). In Brasilia, although there was no difference in prevalence between men and women, among women, however, higher education was a protective factor for metabolic syndrome $e^{25}$. We found that in this population of high education 
Table 3. Lifestyle and anthropometric variables among university students according to sex, São Luís, Maranhão, Brazil, 2011-12.

\begin{tabular}{|c|c|c|c|c|c|c|c|}
\hline \multirow[b]{2}{*}{ Variables } & \multicolumn{2}{|c|}{ Females } & \multicolumn{2}{|c|}{ Males } & \multicolumn{2}{|c|}{ Total } & \multirow[b]{2}{*}{ P-value } \\
\hline & n & $\begin{array}{c}\% \\
\text { weighted }\end{array}$ & $\mathbf{n}$ & $\begin{array}{c}\% \\
\text { weighted }\end{array}$ & n & $\begin{array}{c}\% \\
\text { weighted }\end{array}$ & \\
\hline Smoking & & & & & & & $<0.001$ \\
\hline Yes & 16 & 2.1 & 25 & 8.0 & 41 & 4.3 & \\
\hline No & 572 & 95.1 & 305 & 86.8 & 877 & 92.0 & \\
\hline Ex-smoker & 23 & 2.9 & 18 & 5.3 & 41 & 3.8 & \\
\hline Alcohol Consumption in the last month & & & & & & & 0.004 \\
\hline Yes & 256 & 45.0 & 199 & 58.6 & 513 & 50.2 & \\
\hline No & 358 & 55.0 & 155 & 41.4 & 455 & 49.8 & \\
\hline Physical activity ${ }^{\mathrm{b}}$ & & & & & & & $<0.001$ \\
\hline Sedentary & 454 & 76.1 & 216 & 59.0 & 670 & 69.6 & \\
\hline Sufficient & 100 & 15.3 & 70 & 18.8 & 170 & 16.6 & \\
\hline Active & 60 & 8.6 & 68 & 22.2 & 128 & 13.8 & \\
\hline Block score ${ }^{c}$ & & & & & & & 0.058 \\
\hline Normal & 411 & 67.1 & 251 & 74.9 & 662 & 70.1 & \\
\hline High & 199 & 32.9 & 103 & 25.1 & 302 & 29.9 & \\
\hline Nutritional status - Body mass index & & & & & & & $<0.001$ \\
\hline Low weight & 57 & 9.1 & 13 & 3.0 & 70 & 6.8 & \\
\hline Eutrophic & 381 & 60.6 & 175 & 45.8 & 556 & 55.0 & \\
\hline Overweight & 134 & 23.7 & 132 & 39.1 & 266 & 29.5 & \\
\hline Obesity & 42 & 6.7 & 34 & 12.0 & 76 & 8.7 & \\
\hline Waist-to-hip ratio ${ }^{\mathrm{d}}$ & & & & & & & 0.023 \\
\hline Normal & 523 & 83.4 & 269 & 71.5 & 792 & 78.9 & \\
\hline High & 91 & 16.6 & 85 & 28.5 & 176 & 21.1 & \\
\hline Waist-to-height ratio ${ }^{\mathrm{e}}$ & & & & & & & 0.002 \\
\hline Normal & 493 & 79.0 & 232 & 60.9 & 725 & 72.1 & \\
\hline High & 121 & 21.0 & 122 & 39.1 & 243 & 27.9 & \\
\hline Body fat percentage $e^{f}$ & & & & & & & 0.525 \\
\hline Obesity & 154 & 24.3 & 62 & 21.0 & 216 & 23.0 & \\
\hline Normal & 448 & 73.7 & 284 & 77.8 & 732 & 75.2 & \\
\hline Malnutrition & 12 & 2.0 & 8 & 1.3 & 20 & 1.8 & \\
\hline
\end{tabular}

${ }^{\text {a }} \mathrm{P}$ value calculated by the chi-square test; ${ }^{\mathrm{b}}$ Physical activity evaluated and classified according to guidelines from the International Physical Activity Questionnaire; ${ }^{\mathrm{c}}$ Block score - high fat consumption - score $>27$; ${ }^{\mathrm{d}}$ High waist-to-hip ratio $\geq 0.90$ for males and $\geq 0.85$ for females; ${ }^{\mathrm{e}}$ High waist-to-height ratio $\geq 0.53$ for males and $\geq 0.52$ for females; ${ }^{\mathrm{f}}$ Body fat percentage measured by bipolar bioelectrical impedance - obesity $\geq 25 \%$ for men and $\geq 32 \%$ for women, malnutrition $<6 \%$ for men and $<8.9 \%$ for women.

students, women had a lower prevalence of MS than men.

In another population-based study in Vitória with adults aged 25 to 64 years in 1999 and 2000, the prevalence of MS by the NCEP definition was $29.8 \%$, with no difference between sexes ${ }^{26}$. The prevalence of MS by the NCEP criterion among 25-34 year olds (15.8\%) in Vitória was very similar to that observed in this study for the younger age group (14.9\%). Another study by Marquezine et $a .^{27}$ with the urban population of Vitoria, found a lower prevalence of MS by the NCEP in the young age group, $12.3 \%$ for the age group
25-35 years, compared to this study. In this study, the prevalence of MS by the NCEP was higher for males $(22.1 \%)$ than for females $(10.7 \%$, p = $0.019)$, which differs from most studies that did not find a significant difference in the prevalence of MS according to sex.

The high prevalence of MS among male college students in the sample studied in São Luís, may be explained by the fact that the student population is composed of individuals of higher income and education. The worse cardiovascular risk profile observed in men seems to be a portrait of the most advantaged social groups. At the 
Table 4. Metabolic syndrome and its components, and insulin resistance among university students according to sex, São Luís, Maranhão, Brazil, 2011-12.

\begin{tabular}{|c|c|c|c|c|c|c|c|}
\hline \multirow[b]{2}{*}{ Variables } & \multicolumn{2}{|c|}{ Females } & \multicolumn{2}{|c|}{ Males } & \multicolumn{2}{|c|}{ Total } & \multirow[b]{2}{*}{ P-value } \\
\hline & $\mathbf{n}$ & $\begin{array}{c}\% \\
\text { weighted }\end{array}$ & $\mathbf{n}$ & $\begin{array}{c}\% \\
\text { weighted }\end{array}$ & $\mathbf{n}$ & $\begin{array}{c}\% \\
\text { weighted }\end{array}$ & \\
\hline $\begin{array}{l}\text { Waist circumference by the NCEP } \\
\text { definition }^{\text {b }}\end{array}$ & & & & & & & 0.512 \\
\hline Normal & 525 & 85.1 & 325 & 88.2 & 850 & 86.3 & \\
\hline High & 89 & 14.9 & 29 & 11.8 & 118 & 13.7 & \\
\hline $\begin{array}{l}\text { Waist circumference by the IDF } \\
\text { definition }^{c}\end{array}$ & & & & & & & 0.550 \\
\hline Normal & 416 & 65.0 & 237 & 62.3 & 653 & 64.0 & \\
\hline High & 198 & 35.0 & 117 & 37.7 & 315 & 36.0 & \\
\hline Hypertension $^{\mathrm{d}}$ & & & & & & & $<0.001$ \\
\hline No & 536 & 84.7 & 205 & 53.7 & 741 & 72.9 & \\
\hline Yes & 77 & 15.3 & 149 & 46.3 & 226 & 27.1 & \\
\hline Glycemia $^{e}$ & & & & & & & 0.047 \\
\hline Normal & 371 & 97.4 & 201 & 92.3 & 572 & 95.5 & \\
\hline High & 11 & 2.6 & 12 & 7.8 & 23 & 4.5 & \\
\hline Triglycerides $^{\mathrm{f}}$ & & & & & & & 0.002 \\
\hline Normal & 349 & 89.5 & 177 & 71.3 & 526 & 82.7 & \\
\hline High & 32 & 10.5 & 34 & 28.7 & 66 & 17.3 & \\
\hline HDL-cholesterolg & & & & & & & 0.072 \\
\hline Normal & 122 & 35.3 & 97 & 44.9 & 219 & 38.9 & \\
\hline Low & 260 & 64.7 & 114 & 55.2 & 374 & 61.2 & \\
\hline Metabolic Syndrome - NCEP & & & & & & & 0.027 \\
\hline No & 351 & 89.3 & 184 & 77.9 & 535 & 85.1 & \\
\hline Yes & 29 & 10.7 & 26 & 22.1 & 55 & 14.9 & \\
\hline Metabolic Syndrome-IDF & & & & & & & 0.022 \\
\hline No & 340 & 86.6 & 175 & 73.4 & 515 & 81.7 & \\
\hline Yes & 40 & 13.4 & 35 & 26.6 & 75 & 18.3 & \\
\hline Metabolic Syndrome -JIS & & & & & & & $<0.001$ \\
\hline No & 339 & 86.5 & 168 & 67.8 & 507 & 79.6 & \\
\hline Yes & 41 & 13.5 & 42 & 32.2 & 83 & 20.5 & \\
\hline Insulin Resistance - HOMA-IR ${ }^{\mathrm{h}}$ & & & & & & & 0.636 \\
\hline No & 355 & 92.1 & 199 & 93.7 & 554 & 92.7 & \\
\hline Yes & 27 & 7.9 & 13 & 6.3 & 40 & 7.3 & \\
\hline
\end{tabular}

a $\mathrm{P}$ value calculated by the chi-square test; ${ }^{\mathrm{b}} \mathrm{High}$ waist circumference according to the NCP criterion $\geq 102 \mathrm{~cm}$ for males and $\geq 88$ $\mathrm{cm}$ for females; ${ }^{\mathrm{c}}$ High waist circumference according to the IDF criterion $\geq 90 \mathrm{~cm}$ for males and $\geq 80 \mathrm{~cm}$ for females;

${ }^{\mathrm{d}}$ Hypertension - systolic blood pressure $\geq 130 \mathrm{mmHg}$ and/or diastolic blood pressure $\geq 85 \mathrm{mmHg}$; ${ }^{\mathrm{C}}$ Hyperglycemia $\geq 100 \mathrm{mg} / \mathrm{dl}$; ${ }^{\mathrm{f}}$ Hypertriglyceridemia $\geq 150 ;{ }^{\mathrm{g}}$ Low HDL-cholesterol $<40 \mathrm{mg} / \mathrm{dl}$ for men and $<50 \mathrm{mg} / \mathrm{dl}$ for women; ${ }^{\text {h HOMA }-I R: ~ H o m e o s t a s i s ~}$ Model Assessment - insulin resistance $>2.7$.

HDL: High Density Lipoprotein; NCEP: National Cholesterol Education Program; IDF: International Diabetes Federation; JIS: Joint Interim Statement.

University of Kansas, in the United States, men were more obese, more hypertriglyceridemic and hypertensive than women ${ }^{28}$, in accordance with findings from this study.

This study also showed that in this population of university students, composed predominantly of middle and high-income individuals, paradoxically, men were more obese than women, despite being more physically active and having a lower percentage of high fat intake. Part of the explanation for this apparent paradox could be a higher intake of carbohydrates by men, but unfortunately, we did not obtain this information. As this is a cross-sectional study, another possible explanation is that men being more obese have so practiced more physical activities and ate less fat, trying to lose weight. The association between low fat intake and a less sedentary lifestyle with worse cardiovascular risk profile among men would then be explained by reverse 
Table 5. Lifestyle and anthropometric variables among university students attending public or private institutions, São Luís, Maranhão, Brazil, 2011-12.

\begin{tabular}{|c|c|c|c|c|c|}
\hline \multirow[b]{2}{*}{ Variables } & \multicolumn{2}{|c|}{ Public } & \multicolumn{2}{|c|}{ Private } & \multirow[b]{2}{*}{ P-value } \\
\hline & n & $\begin{array}{c}\% \\
\text { weighted }\end{array}$ & $\mathbf{n}$ & $\begin{array}{c}\% \\
\text { weighted }\end{array}$ & \\
\hline Smoking & & & & & 0.347 \\
\hline Yes & 13 & 3.6 & 28 & 4.6 & \\
\hline No & 375 & 93.9 & 502 & 91.0 & \\
\hline Ex-smoker & 11 & 2.5 & 30 & 4.4 & \\
\hline Alcohol Consumption in the last month & & & & & 0.340 \\
\hline Yes & 173 & 46.7 & 282 & 52.0 & \\
\hline No & 231 & 53.3 & 282 & 48.0 & \\
\hline Physical activity ${ }^{\mathrm{b}}$ & & & & & 0.019 \\
\hline Sedentary & 262 & 62.6 & 408 & 73.3 & \\
\hline Sufficient & 86 & 22.1 & 84 & 13.7 & \\
\hline Active & 56 & 15.3 & 72 & 13.0 & \\
\hline Block score ${ }^{c}$ & & & & & 0.576 \\
\hline Normal & 282 & 71.8 & 380 & 69.2 & \\
\hline High & 121 & 28.2 & 181 & 30.8 & \\
\hline Nutritional status - Body mass index & & & & & 0.024 \\
\hline Low weight & 29 & 6.7 & 41 & 6.8 & \\
\hline Eutrophic & 257 & 62.3 & 299 & 51.1 & \\
\hline Overweight & 95 & 25.2 & 171 & 31.8 & \\
\hline Obesity & 23 & 5.7 & 53 & 10.3 & \\
\hline Waist-to-hip ratio ${ }^{\mathrm{d}}$ & & & & & 0.001 \\
\hline Normal & 355 & 86.4 & 437 & 74.9 & \\
\hline High & 49 & 13.6 & 127 & 25.1 & \\
\hline Waist-to-height ratio ${ }^{e}$ & & & & & $<0.001$ \\
\hline Normal & 327 & 81.2 & 398 & 67.3 & \\
\hline High & 77 & 18.8 & 166 & 32.7 & \\
\hline Body fat percentage ${ }^{f}$ & & & & & 0.001 \\
\hline Obesity & 61 & 15.6 & 155 & 26.9 & \\
\hline Normal & 332 & 82.4 & 400 & 71.5 & \\
\hline Malnutrition & 11 & 2.0 & 9 & 1.6 & \\
\hline
\end{tabular}

${ }^{a} \mathrm{P}$ value calculated by the chi-square test; ${ }^{\mathrm{b}}$ Physical activity evaluated and classified according to guidelines from the International Physical Activity Questionnaire; ${ }^{\mathrm{c}}$ Block score - high fat consumption - score $>27$; ${ }^{\mathrm{d}}$ High waist-to-hip ratio $\geq 0.90$ for males and $\geq 0.85$ for females; ${ }^{\mathrm{e}} \mathrm{High}$ waist-to-height ratio $\geq 0.53$ for males and $\geq 0.52$ for females; ${ }^{\mathrm{f}}$ Body fat percentage measured by bipolar bioelectrical impedance - obesity $\geq 25 \%$ for men and $\geq 32 \%$ for women, malnutrition $<6 \%$ for men and $<8.9 \%$ for women.

causality. Another possibility is that women are more concerned with their body image and even being more sedentary, have a lower cardiovascular risk by adhering to a healthier diet.

The prevalence of hypertension in this study (27.1\%) was higher than that observed by Simon et al..$^{29}(23.5 \%)$, Mascena et al..$^{10}(15.8 \%)$ and Martins et al..$^{30}(9.7 \%)$ in university samples of similar age. In another population-based study conducted in São Luís, in adults with a mean age of 39.4 ( \pm 16.6$)$ years, high prevalence of hypertension was found in $27.4 \%{ }^{31}$. The big difference in the prevalence of hypertension among men
$(46.3 \%)$ and women $(15.3 \%)$ detected in this study, was probably due to the fact that most risk factors for cardiovascular disease are more prevalent in males than females. This difference was also found in other studies ${ }^{10,30,31}$.

We found a very high prevalence of low HDL-C (61.2\%). High prevalence of low HDL-C is associated with increased waist circumference and a sedentary life style ${ }^{32}$, and both were highly prevalent in the current study $(36.0 \%$ and $69.6 \%$, respectively). In some studies, a high prevalence of low HDL-C was also observed, although smaller than that found in the present stud: $44.1 \%$ in a 
Table 6. Metabolic syndrome and its components, and insulin resistance among university students attending public or private institutions, São Luís, Maranhão, Brazil, 2011-12.

\begin{tabular}{|c|c|c|c|c|c|}
\hline \multirow[b]{2}{*}{ Variables } & \multicolumn{2}{|c|}{ Public } & \multicolumn{2}{|c|}{ Private } & \multirow[b]{2}{*}{ P-value ${ }^{a}$} \\
\hline & $\mathbf{n}$ & $\begin{array}{c}\% \\
\text { weighted }\end{array}$ & n & $\begin{array}{c}\% \\
\text { weighted }\end{array}$ & \\
\hline $\begin{array}{l}\text { Waist circumference by the NCEP } \\
\text { definition }^{\text {b }}\end{array}$ & & & & & 0.007 \\
\hline Normal & 375 & 91.4 & 475 & 83.6 & \\
\hline High & 29 & 8.6 & 89 & 16.4 & \\
\hline $\begin{array}{l}\text { Waist circumference by the IDF } \\
\text { definition }^{c}\end{array}$ & & & & & $<0.001$ \\
\hline Normal & 312 & 76.6 & 341 & 57.3 & \\
\hline High & 92 & 23.4 & 223 & 42.7 & \\
\hline Hypertension $^{\mathrm{d}}$ & & & & & 0.863 \\
\hline No & 309 & 72.4 & 432 & 73.2 & \\
\hline Yes & 95 & 27.6 & 131 & 26.8 & \\
\hline Glycemia $^{e}$ & & & & & 0.351 \\
\hline Normal & 306 & 96.8 & 266 & 94.8 & \\
\hline High & 12 & 3.3 & 11 & 5.2 & \\
\hline Triglycerides ${ }^{\mathrm{f}}$ & & & & & 0.002 \\
\hline Normal & 294 & 91.5 & 232 & 77.9 & \\
\hline High & 21 & 8.5 & 45 & 22.1 & \\
\hline HDL-cholesterol ${ }^{\mathrm{g}}$ & & & & & 0.228 \\
\hline Normal & 125 & 44.8 & 94 & 35.6 & \\
\hline Low & 192 & 55.2 & 182 & 64.4 & \\
\hline Metabolic Syndrome - NCEP & & & & & 0.115 \\
\hline No & 295 & 90.9 & 240 & 81.9 & \\
\hline Yes & 20 & 9.1 & 35 & 18.1 & \\
\hline Metabolic Syndrome-IDF & & & & & $<0.001$ \\
\hline No & 292 & 91.7 & 223 & 76.3 & \\
\hline Yes & 23 & 8.3 & 52 & 23.7 & \\
\hline Metabolic Syndrome -JIS & & & & & 0.016 \\
\hline No & 287 & 88.7 & 220 & 74.6 & \\
\hline Yes & 28 & 11.3 & 55 & 25.5 & \\
\hline Insulin Resistance - HOMA-IR ${ }^{\mathrm{h}}$ & & & & & 0.922 \\
\hline No & 298 & 92.5 & 256 & 92.9 & \\
\hline Yes & 20 & 7.5 & 20 & 7.1 & \\
\hline
\end{tabular}

${ }^{a} \mathrm{P}$ value calculated by the chi-square test; ${ }^{\mathrm{b}} \mathrm{High}$ waist circumference according to the NCP criterion $\geq 102 \mathrm{~cm}$ for males and $\geq 88 \mathrm{~cm}$ for females; ${ }^{\mathrm{c}} \mathrm{High}$ waist circumference according to the IDF criterion $\geq 90 \mathrm{~cm}$ for males and $\geq 80 \mathrm{~cm}$ for females;

${ }^{\mathrm{d}}$ Hypertension - systolic blood pressure $\geq 130 \mathrm{mmHg}$ and/or diastolic blood pressure $\geq 85 \mathrm{mmHg}$; ${ }^{\mathrm{C}}$ Hyperglycemia $\geq 100 \mathrm{mg} / \mathrm{dl}$; ${ }^{\mathrm{f}}$ Hypertriglyceridemia $\geq 150$; ${ }^{\mathrm{g}}$ Low HDL-cholesterol $<40 \mathrm{mg} / \mathrm{dl}$ for men and $<50 \mathrm{mg} / \mathrm{dl}$ for women; ${ }^{\mathrm{h}} \mathrm{HOMA}$-IR: Homeostasis Model Assessment - insulin resistance $>2.7$.

HDL: High Density Lipoprotein; NCEP: National Cholesterol Education Program; IDF: International Diabetes Federation; JIS: Joint Interim Statement.

rural area of Minas Gerais, Brazil ${ }^{33}$, and $21.1 \%$ in adults aged 30-39 years in São Carlos, São Paulo, Brazil $^{29}$.

A higher prevalence of cardiovascular risk factors found among students from private compared to those who attend public institutions can be justified by the higher income of students from private universities. National studies show a higher prevalence of overweight $(p=0.004)^{34}$ and increased waist circumference $(\mathrm{p}=0.008)^{35}$ in high-income individuals.

Among the strengths of this study we outline: it is a population-based sample of young adults, age at which few population studies have been conducted in Brazil. The percentage of losses was satisfactory $(24.1 \%)$. Participation rate was higher for students from public (78\%) than private (72\%) institutions. However, the participation 
Table 7. Comparison of some characteristics between those who did or did not attend blood collection, São Luís, Maranhão, Brazil, 2011-12.

\begin{tabular}{|c|c|c|c|}
\hline \multirow[b]{2}{*}{ Variables } & \multicolumn{2}{|c|}{ Attended blood collection } & \multirow{2}{*}{ P-value } \\
\hline & $\begin{array}{c}\text { Yes } \\
\text { \% weighted }\end{array}$ & $\begin{array}{c}\text { No } \\
\text { \% weighted }\end{array}$ & \\
\hline Sex & & & 0.707 \\
\hline Female & 58.2 & 41.8 & \\
\hline Male & 56.2 & 43.8 & \\
\hline Age (years) & & & 0.921 \\
\hline$\leq 20$ & 59.1 & 40.9 & \\
\hline 21 to 30 & 56.8 & 43.2 & \\
\hline$\geq 30$ & 57.2 & 42.8 & \\
\hline Family income (minimum wages) & & & 0.034 \\
\hline$<2$ & 61.5 & 38.5 & \\
\hline 2 to 4 & 62.3 & 37.7 & \\
\hline 5 to 9 & 61.0 & 39.0 & \\
\hline$\geq 10$ & 44.7 & 55.4 & \\
\hline Schooling of the head of family & & & 0.003 \\
\hline College/University Degree & 51.3 & 48.7 & \\
\hline High School & 55.6 & 44.4 & \\
\hline Primary or Middle School & 74.9 & 25.1 & \\
\hline Brazilian Economic Classification & & & 0.259 \\
\hline $\mathrm{A} / \mathrm{B}$ & 53.2 & 46.8 & \\
\hline $\mathrm{C}$ & 59.8 & 40.2 & \\
\hline $\mathrm{D} / \mathrm{E}$ & 64.5 & 35.5 & \\
\hline Stratum & & & $<0.001$ \\
\hline Public & 79.3 & 20.7 & \\
\hline Private & 46.0 & 54.0 & \\
\hline Marital status & & & 0.062 \\
\hline Without a companion & 57.9 & 42.1 & \\
\hline Consensual union & 33.4 & 66.6 & \\
\hline Married & 60.5 & 39.5 & \\
\hline Skin color & & & 0.845 \\
\hline White & 56.7 & 43.3 & \\
\hline Black & 55.4 & 44.6 & \\
\hline Mullato & 58.5 & 41.5 & \\
\hline Religion & & & 0.009 \\
\hline Catholic & 54.5 & 45.5 & \\
\hline Evangelic & 64.9 & 35.1 & \\
\hline Other & 69.4 & 30.6 & \\
\hline No religion & 47.9 & 52.1 & \\
\hline Health Insurance & & & 0.012 \\
\hline Yes & 51.2 & 48.8 & \\
\hline No & 62.9 & 37.1 & \\
\hline
\end{tabular}

${ }^{\text {a } P}$ value calculated by the chi-square test.

rate for laboratory examinations was low, $61 \%$, being higher for public (78\%) than private (49\%) universities. Fewer university students with higher family income, higher educational level of household head, private institutions, from catholic backgrounds, who had no religion or who had health insurance attended blood collection. Due to the smaller percentage of attendance for laboratory tests, prevalences were weighted by the inverse probability of selection of each individual, taking non-response into account. It has been shown that in the presence of losses, inverse probability weighting is a method that reduces selection bias ${ }^{36}$. Prevalence of MS according to JIS was $18.1 \%$ and increased to $20.5 \%$ after inverse probability weighting taking non-response 
into account was used, which shows that this method was able to attenuate underestimation of MS in the population. Even with this correction it is still possible that the prevalence of MS is underestimated in this study if not all predictors of participation in laboratorial exams were included in the logistic regression model.

\section{Collaborations}

JB Barbosa worked in the study design, analysis and interpretation of data, and drafted the article; AM Santos worked on the analysis and interpretation of data; MM Barbosa, JM Fonseca, MCL Barbosa and MM Barbosa collaborated in the study design and helped in data interpretation; CA Carvalho and PCA Fonseca worked in the study design and data analysis; EG Bogéa worked in data analysis and interpretation, and wrote the final version of the manuscript; AAM Silva conceived the study and helped in data analysis and interpretation. All authors reviewed and approved the final version.

\section{Conclusion}

High prevalences of metabolic syndrome (20.5\% according to the JIS definition), insulin resistance $(7.3 \%)$ and other cardiovascular risk factors were found in this young population. This suggests that the burden of these diseases in the future will be increased, especially among men and students from private universities. 


\section{Acknowledgments}

We thanked the Maranhão State Research Foundation (FAPEMA in the Portuguese acronym), UDI Hospital and Laboratório Cedro for providing financial and logistic support.

\section{References}

1. Correia BR, Cavalcante E, Santos E. A prevalência de fatores de risco para doenças cardiovasculares em estudantes universitários. Rev Bras Clin Med 2010; 8(1):2529.

2. Carvalho Vidigal F, Bressan J, Babio N, Salas-Salvado J. Prevalence of metabolicsyndrome in Brazilianadults: a systematicreview. BMC publichealth 2013; 13:1198.

3. Brasil. Ministério da Saúde (MS). Rede Interagencial de Informações para a Saúde (Ripsa). DATASUS. Indicadores e dados básicos para a saúde. Brasília: MS; 2012.

4. Costa F, Montenegro VB, Lopes TJA, Costa EC. Combinação de fatores de risco relacionados à síndrome metabólica em militares da Marinha do Brasil. Arqbrascardiol 2011; 97:485-492.

5. Felipe-de-Melo ERT, Silva RCR, Assis AMO, Pinto EJ. Fatores associados à síndrome metabólica em trabalhadores administrativos de uma indústria de petróleo. Cien Saude Colet 2011; 16(8):3443-3452.

6. Sociedade Brasileira de cardiologia. I Diretriz Brasileira de Diagnóstico e Tratamento da Síndrome Metabólica. Arqbrascardiol 2005; 84(Supl.1).

7. Gasparotto GS, Gasparotto LP, de Salles MR, Campos W. Fatores de risco cardiovascular em universitários: comparação entre sexos, períodos de graduação e áreas de estudo. Medicina (Ribeirao Preto Online). 2013; 46(2):154-163.

8. Feliciano-Alfonso JE, Mendivil CO, Ariza IDS, Pérez CE. Cardiovascular risk factors and metabolic syndrome in a population of young students from the National University of Colombia. Revista da Associação Medica Brasileira 2010; 56(3):293-298.

9. Zemdegs JCS, Corsi LB, Coelho L, Pimentel GD, Hirai AT, Sachs A. Lipid profile and cardiovascular risk factors among first-year Brazilian university students in São Paulo. Nutr Hosp 2011; 26(3):553-559.

10. Mascena GV, Cavalcante MSB, Marcelino GB, Holanda SA, Brandt CT. Fatores de risco cardiovascular em estudantes da Faculdade de Ciências Médicas de Campina Grande. Medicina (Ribeirao Preto Online) 2012; 45(3):332-338.

11. Instituto Brasileiro de Geografia e Estatística (IBGE). Pesquisa de Orçamentos Familiares 2008-2009. Antropometria e Estado Nutricional de Crianças, Adolescentes e Adultos no Brasil. Rio de Janeiro: IBGE; 2010.

12. Muller EV, Aranha SRR, da Roza WSS, Gimeno SGA. Distribuição espacial da mortalidade por doenças cardiovasculares no Estado do Paraná, Brasil: 1989-1991 e 2006-2008. Cad Saude Publica 2012; 28(6):1067-1077.

13. Bustos P, Silva AAM, Amigo H, Bettiol H, Barbieri MA. Metabolic syndrome in young adults from two socioeconomic Latin American settings. Nut Metab Cardiovasc Dis 2007; 17(8):581-589.

14. Block G, Clifford C, Naughton MD, Henderson M, McAdams M. A brief dietary screen for high fat intake. Journal of Nutrition Education 1989; 21(5):199-207.

15. Sociedade Brasileira de Cardiologia. VI Diretrizes Brasileiras de Hipertensão. Arq Bras Cardiol 2010; 95(Supl. 1):1-51.

16. Lohman TG. Advances in body composition assessment. Champaign: Human Kinetics Publishers; 1992.

17. World Health Organization (WHO). Obesity: preventing and managing the global epidemic. Geneva: WHO; 1998. Report of a WHO Consultation on obesity. 
18. Vitolo MRV. CLAO: Consenso Latino-americano de Obesidade, 1998. In: Vitolo MRV. Nutrição: da gestação ao envelhecimento. Rio de Janeiro: Rubio; 2008.

19. Alberti KG, Eckel RH, Grundy SM, Zimmet PZ, Cleeman JI, Donato KA, Fruchart JC, James WP, Loria CM, Smith SC Jr; International Diabetes Federation Task Force on Epidemiology and Prevention; Hational Heart, Lung, and Blood Institute; American Heart Association; World Heart Federation; International Atherosclerosis Society; International Association for the Study of Obesity. Harmonizing the Metabolic Syndrome: A Joint Interim Statement of the International Diabetes Federation Task Force on Epidemiology and Prevention; National Heart, Lung, and Blood Institute; American Heart Association; World Heart Federation; International Atherosclerosis Society; and International Association for the Study of Obesity. Circulation 2009; 120(16):1640-1645.

20. Ybarra J, Sanchez-Hernandez J, Pou JM, Fernández S, Gich I, Ordóñez-Llanos J, Jurado J, Leiva A, Pérez A. Anthropometrical measures are easily obtainable sensitive and specific predictors of insulin resistance in healthy individuals. Prevention and Control 2005; 1(2):175-181.

21. Wallace TM, Levy JC, Matthews DR. Use and abuse of HOMA modeling. Diabetes Care 2004; 27(6):14871495

22. Geloneze B, Vasques ACJ, Stabe CFC, Pareja JC, Rosado LEFP, Queiroz EC, Tambascia MA; BRAMS Investigators. HOMA1-IR and HOMA2-IR indexes in identifying insulin resistance and metabolic syndrome: Brazilian Metabolic Syndrome Study (BRAMS). Arquivos Brasileiros de Endocrinologia \& Metabologia. 2009; 53(2):281-287.

23. Zimmet P, Alberti KG, Kaufman F, Tajima N, Silink M, Arslanian S, Wong G, Bennett P, Shaw J, Caprio S; IDF Consensus Group. The metabolic syndrome in children and adolescents - an IDF consensus report. Pediatr Diabetes 2007; 8(5):299-306.

24. Matsudo S, Araújo T, Matsudo V, Andrade D, Andrade E, Oliveira LC, Braggion G. Questionário Internacional de Atividade Física (IPAQ):estudo de validade e reprodutibilidade no Brasil. Rev Ativ Fís Saúde 2001; 6(2):5-18.

25. Dutra ES, de Carvalho K, Miyazaki É, Hamann EM, Ito MK. Metabolic syndrome in central Brazil: prevalence and correlates in the adult population. Diabetol Metab Syndr 2012; 4(1):20.

26. Salaroli LB, Barbosa GC, Mill JG, Molina MC. Prevalência de síndrome metabólica em estudo de base populacional, Vitória, ES-Brasil. Arq Bras endocrinol metab 2007; 51(7):1143-1152.

27. Marquezine GF, Oliveira CM, Pereira AC, Krieger JE, Mill JG. Metabolic syndrome determinants in an urban population from Brazil: Social class and gender-specific interaction. Int J Cardiol 2008; 129(2):259-265.
28. Huang TTK, Shimel A, Lee RE, Delancey W, Strother ML. Metabolic risks among college students: prevalence and gender differences. Metab Syndr Relat Disord. 2007; 5(4):365-372.

29. Simon E, Silva TT, Barbosa JSO, Rodrigues RD, Jesus Teixeira R. Fatores de risco cardiovascular-Perfil clínico e epidemiológico dos participantes do projeto Atividade Física na Vila. RELATO DE CASO Projeto Famílias Unidas: atendimento psicoterapêutico à população em situação de risco social. Ver Bras Med Fam Com 2007; 2(8):288-297.

30. Martins MCC, Ricarte IF, Rocha CHL, Maia RB, Silva VB, Veras AB, Souza Filho MD. Pressão Arterial, Excesso de Peso e Nível de Atividade Física em Estudantes de Universidade Pública. Arq Bras Cardiol 2010; 95(2):192-199.

31. Barbosa JB, Silva AAM, Santos AM, Monteiro Júnior FC, Barbosa MM, Barbosa MM, Figueiredo Neto JA, Soares NJS, Nina VJS, Barbosa JN. Prevalência da Hipertensão Arterial em Adultos e Fatores Associados em São luís - MA. Arq Bras Cardiol 2008; 91(4):260-266.

32. Byun W, Dowda M, Pate RR. Associations between screen-based sedentary behavior and cardiovascular disease risk factors in Korean youth. J Korean Med Sci 2012; 27(4):388-394.

33. Pimenta AM, Gazzinelli A, Velásquez-Meléndez G. Prevalência da síndrome metabólica e seus fatores associados em área rural de Minas Gerais (MG, Brasil). Cien Saude Colet 2011; 16(7):3297-3306.

34. Lino MZR, Muniz PT, Siqueira KS. Prevalência e fatores associados ao excesso de peso em adultos: inquérito populacional em Rio Branco, Acre, Brasil, 2007-2008. Cad Saude Publica 2011; 27(4):797-810.

35. Pinho CPPS, Diniz AS, Arruda IKG, Batista Filho M, Coelho PC, Sequeira LAS, Sequeira LAS, Lira PIC. Prevalência e fatores associados à obesidade abdominal em indivíduos na faixa etária de 25 a 59 anos do Estado de Pernambuco, Brasil. Cad Saude Publica 2013; 29(2):313-324.

36. Seaman SR, White IR. Review of inverse probability weighting for dealing with missing data. Stat Methods Med Res. 2013; 22(3):278-295.

Artigo apresentado em 15/06/2015

Aprovado em 13/08/2015

Versão final apresentada em 15/08/2015 